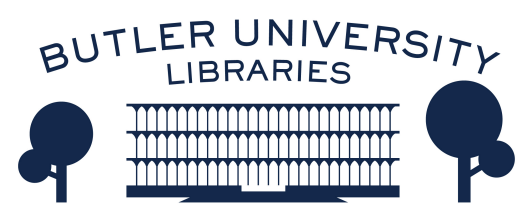

Journal of Hindu-Christian Studies

Volume 25

Article 18

November 2012

\title{
Book Review: "Baby Krishna, Infant Christ," Kristin Johnston Largen
}

Arun W. Jones

Follow this and additional works at: https://digitalcommons.butler.edu/jhcs

Part of the Religion Commons

\section{Recommended Citation}

Jones, Arun W. (2012) "Book Review: "Baby Krishna, Infant Christ," Kristin Johnston Largen," Journal of Hindu-Christian Studies: Vol. 25, Article 18.

Available at: https://doi.org/10.7825/2164-6279.1524

The Journal of Hindu-Christian Studies is a publication of the Society for Hindu-Christian Studies. The digital version is made available by Digital Commons @ Butler University. For questions about the Journal or the Society, please contact cbauman@butler.edu. For more information about Digital Commons @ Butler University, please contact digitalscholarship@butler.edu. 
Sheveland hopes to contribute with this book. One thing is certain: such theological practice, if it is to be faithful to Rahner, Barth or Desika, must be deeply pious, self-consciously open to the grace of God, and, as a response to this grace, radically accountable to the needs of "the other," the neighbor and indeed the global community. Sheveland's work exemplifies both virtues, even as it sets broader, interreligious conversations about love and solidarity on a new footing.

Reid B. Locklin

St. Michael's College, University of Toronto

\section{Baby Krishna, Infant Christ. Kristin Johnston Largen. Maryknoll, NY: Orbis Books, 2011, $\mathrm{x}+246$ pages.}

THE subtitle of this clearly written and well organized volume, subtitled A Comparative Theology of Salvation, signals the author's purpose in undertaking her study. Kristin Johnston Largen, who approaches her subject as a Lutheran theologian, is not simply interested in comparing Christ and Krishna and the ways they offer salvation to their followers. Rather, she wishes to help North American Protestants expand their notions of the divine by gaining an appreciation for the Hindu deity Krishna, whose life and meaning are elucidated in light of the more familiar figure of Christ.

The book opens with an Introduction that ushers in the two persons of the study, and lays out a helpful road map for the rest of the work. Chapter One deals with the emerging discipline of Comparative Theology: the author's understanding of it, a defense for its existence in the life of the Christian church, and the possible benefits for Christians who engage this discipline. Part I of the book follows, with two chapters focusing on Krishna. After a brief overview of Hinduism, Krishna's life is described, with an emphasis on his childhood. Then comes a discussion of how Krishna saves his followers, through play (lila), loving devotion (bhakti), and the revelation of the true nature of reality (samsara) from which he offers liberation (moksha).

Part II, also consisting of two chapters, concerns Jesus Christ. The infancy and youth narratives in the Bible are covered, and then the author turns to the non-canonical, apocryphal gospels, where there is much more material concerning the infancy, childhood and youth of Jesus. Stories from the Infancy Gospel of James and the Infancy Gospel of Thomas are related and discussed. Parallel to Part I, the second chapter of Part II discusses how Jesus saves his disciples. An overview of some of the crucial fourth and fifth century Christian debates about the nature and work of Jesus christ is provided, with a discussion of how the birth narratives in the New Testament relate to them. This section on Christian orthodoxy is followed by an interesting foray into the possible theological implications of the childhood narratives in the Infant Gospels of James and of Thomas. Largen here argues that these non-canonical works help us imagine a God who is at play - "a God who is spontaneous, impulsive and inventive" (133) - and a God of emotion - one who, for example, is angry "at those who would exploit and oppress the poor" (144).

Part III, consisting of the two final chapters, considers the adult lives of Krishna and Jesus, and what Christians can learn from material outside the Bible, whether in the Hindu religious tradition or in non-canonical gospels. Largen examines the role of the adult divinities in the lives of their followers, and how some of the themes from the infancy and childhood narratives are developed in the stories from adulthood, while others are dropped. The author discusses Krishna's important role in the Mahabharata and especially the Bhagavad Gita, and what the adult Krishna expects of his followers and how he saves them. Similarly Largen deals with the ministry, death and resurrection of Jesus, and what these mean for the lives and the salvation of his followers. The final chapter of the book sums up lessons that (Protestant) Christians can learn from a study of Krishna and the non-canonical Jesus.

It is important to keep in mind that this book is meant for an audience of committed 
North American Protestants: the section on "What is Hinduism?" does not have an equivalent "What is Christianity?" Given this audience, the work possesses a number of strengths. It is written in a very accessible manner, explaining difficult ideas and complicated stories to a lay readership. It gives parallel treatments of Krishna and of Christ, providing a rough balance between them. It makes a strong case to ordinary Christians that they would benefit in their own religious life by sympathetically examining religious traditions and sources other than their own. Finally, it encourages its readers to expand their notions of the divine in ways that could be helpful to them and to the world.

There are two matters which merit further discussion with the author. The first is her total disregard of the importance of the tradition of the baby Jesus and his mother Mary in Roman Catholicism. The Philippines, for example, has an extremely rich Christian tradition of the Santo Niño. Thus the author's statement that "images of the crucified Jesus predominate" in the collections of "most, if not all Christians who have images of Jesus Christ" is certainly open to question. By ignoring the prominence of the baby Jesus and his mother in Roman Catholicism the author not only misrepresents the Christian tradition, but more importantly misses the opportunity for some very interesting comparative work between the Christian and Hindu traditions in relation to divine infants.

The second matter is the way in which the author links the Jesus narrative with ethical behavior, and the Krishna narrative with nonethical "spiritual" activity. For example, Largen argues that the Jesus infancy narratives urge us not to define humanity simply by rationality, excluding children, "or the mentally ill, or those with diminished mental capabilities" (120). The Jesus infancy narratives also provide a "strong, compelling argument against any and all . . . forms of human degradation, exploitation, and commodification, as they demonstrate clearly that Jesus was fully human from birth" (122). The ethical element remains important in Jesus' adult life: he aligns himself "with outsiders: those who are ostracized and cast out; those who are excluded from community" (172). And when Jesus saves people, "he continually shows his persistence at seeking out those whom it would be easy to overlook and forget" (178). On the other hand, the Krishna story is about the spiritual love of God, according to Largen. Thus "the Gita is a profoundly spiritual and even mystical text about the loving nature of God" (155). Moreover, the "ultimate point of Krishna's engagement with the world-both as a child and as an adult-is to lead people into a higher understanding about the world, to convey the knowledge of the right way to live in order to attain peace and happiness, and finally, to invite them to enter into an ultimate loving relationship with Krishna in order to attain union with the Divine" (167). Perhaps Largen does believe that one of the differences in the soteriological implications of the Krishna and Jesus stories is that the former leads to a spiritual enjoyment with the divine, while the latter leads to a divinely inspired ethical engagement with the world. If so, she should say so, and furthermore admit that this line of thinking has a robust history. Overall, however, Largen has done a great service by introducing the divine life through the prisms of Krishna and the non-canonical Jesus, in ways that could be attractive and compelling to a number of ordinary Christians.

Arun W. Jones

Emory University

\section{Liturgy of Liberation: A Christian Commentary on Shankara's Upadesasahasri. Reid B. Locklin. Grand Rapids: Wm.B.Eerdmans Publishing Company, 2011, xviii + 345 pp.}

REID B. Locklin's, Liturgy of Liberation, is a contribution to a series, "Christian
Commentaries on Non-Christian Sacred Texts," edited by Catherine Cornille. Earlier works in 